\title{
Impact of environmental parameters on fish condition and quality in Lake Edku, Egypt
}

\author{
Samir M. Saeed \\ Central Lab. for Aquaculture Research, Agricultural Research Center. Limnology \\ dept., Egypt.
}

\begin{abstract}
This study was carried out between May 2011 and February 2012 in order to determine the effect of environmental parameters on physical and chemical quality of water, fish condition as well as fish quality in Lake Edku. Fish condition; lengthweight relation, condition factor and hepatosomatic index of three cichlid species $(O$. niloticus, O. aureus and T. zillii) were studied. Also, fish quality as heavy metals accumulation and proximate body composition for muscle tissue of these species were estimated. Physico-chemical parameters were in normal ranges for fish culture and revealed that the lake water showed differences among different seasons. Concentrations of metals in fish muscles have been changed seasonally with higher values recorded during autumn and winter. However, these concentrations are still in the safety permissible levels for human consumption. The best condition and proximate body composition of fish were recorded in spring and winter seasons. According to the results of this study, the most important environmental parameters affecting water characteristics, fish condition and quality in Lake Edku were water temperature, nutrients and drainage water discharged into the lake.
\end{abstract}

Key words: Lake Edku, environmental parameters, fish condition and quality, heavy metals.

\section{INTRODUCTION}

The environmental conditions in water bodies are constantly changed by various natural and human induced factors. The features of the physico-geographical environment of the catchment area, as well as the morphometric parameters of the water body and its hydrological regime, accelerate or block the supply of organic matter to the lakes, which affects its trophic level, water $\mathrm{pH}$ and hardness, its electrolytic conductivity and colouring, light and oxygen availability, and consequently algae and plant species diversity (Chobot and Banaś, 2008).

Physical factors such as climate (i.e. temperature, wind, precipitation, and solar radiation) are also important determinants of water quality in lakes and all critically affect the lake's hydrologic and chemical characteristics, and indirectly affect the composition of the biological community (Najafpour et al., 2008). Also, water quality may be affected by the source of the water, rate of flow, nutrients and algae. Other factors like sewage and agricultural runoffs, various hazardous chemicals and natural contaminants (animal feces) reach the natural sources of water and also pollute the ground water by seeping (Hamill and Verburg, 2010).

Tilapia species are an increasingly important group of cultured fish for several reasons e.g. rapid growth, high tolerance to low water quality, efficiency food conversion, resistance to disease and good consumer acceptance. Water pollution is the most important factor affecting quality and quantity of fish production either in natural habitats or culture ponds. Heavy metals in water considered as the most dangerous source of water pollution (El-Wakil et al., 2008). The accumulation and 
toxicity of metals in aquatic organisms were affected by the environmental conditions (Mason, 2002; Ibrahim et al., 2008).

Chemical body composition of fish could illustrate its physiological condition and health (Saliu et al., 2007). Both condition and quality of fish in lakes are affected by the environmental conditions (Ibrahim et al., 2008) and other biotic and abiotic variables, such as hydrologic level, food availability and water temperature (Wassef and Shehata, 1991; Touhata et al., 1998).

Many studies were conducted on the hydrology, chemical and biological characteristics of Lake Edku (Soliman 1983; Gharib and Soliman, 1998; Siam and Ghobrial, 2000; Okbah and El-Gohary, 2002; Shakweer, 2006; Badr \& Hussein, 2010). However these studies did not investigate whether prevailing conditions (e.g. seasonal variations and physico-chemical characteristics of water) were suitable for well being and quality of fish.

Therefore, the aim of this study was to evaluate the physical and chemical characteristics of Lake Edku water, fish condition (e.g. growth coefficient, condition factor and hepatosomatic index) and quality (metals load and proximate composition) in three major cichlid species and how they fluctuate in relation to different environmental factors as climate (different seasons) and drainage water discharged into the lake.

\section{MATERIALS AND METHODS}

\section{1- Area of the study}

Lake Edku is one of the northern Delta lakes of Egypt and was once considered to be among the most productive lakes of Egypt. It is shallow, brackish and subject to huge inputs of terrigenous and anthropogenic nutrients from drains discharge, sewage and agricultural runoff. The lake is situated west of Rosetta Nile branch (about $30 \mathrm{~km}$ E of Alexandria) between longitudes $30^{\circ} 30^{\prime}$ and $30^{\circ} 23^{\prime} \mathrm{E}$ and Latitudes $31^{\circ} 10^{\prime}$ and $31^{\circ} 18^{`} \mathrm{~N}$ (Fig. 1). It has an average depth of about 1 meter, a surface area of about 85 $\mathrm{km}^{2}$ and water volume of about $85.0 \times 10^{6} \mathrm{~m}^{3}$.

The lake receives its water supply from two main drains; El-Khairy and Barsik drains. The water sources of El-Khairy Drain are from three drainage waters coming from El-Bousely, Edku and Damanhour sub-drains, transporting domestic, agricultural and industrial wastes as well as the drainage water of more than 300 fish farms. Barsik Drain transports mainly agricultural drainage water to the lake. The lake also receives seawater at its north western part through Boughaz El-Maadia from Abu-Kir Bay. Large areas of the originally $150 \mathrm{~km}^{2}$ have disappeared due to land reclamation. The southern part of the lake is characterized by an excessive growth of hydrophytes, such as Phragmites communis and Typha australis (Badr and Hussein, 2010). Nowadays, tilapia and catfish species contribute to more than $80 \%$ of the catch of Lake Edku (GAFRD, 2012). It seems that these fish species have been acclimatized to the prevailing conditions and being able to survive in it forming the main fish population in the lake.

\section{2- Sampling and sites:}

Water and fish samples were collected seasonally from May 2011 to February 2012. Two months/season were selected to represent the whole season. Surface water samples were collected from different stations representing the different ecological areas of Lake Edku (Fig. 1). Values of these stations represented the average of the whole lake in each season. Fish samples (Oreochromis niloticus, Oreochromis aureous and Tilapia zillii) were collected from the commercial catch of Lake Edku at 
El-Nemra 5 Fishery Centre. The mean lengths $( \pm \mathrm{SE})$ were $16.39 \pm 0.05,13.59 \pm 0.11$ and $11.72 \pm 0.11 \mathrm{~cm}$ and the mean weights were $70.79 \pm 0.36,30.03 \pm 0.69$ and $28.42 \pm 0.85 \mathrm{~g}$ for $O$. niloticus, O. aureus and, T. zillii, respectively.

\section{3- Analytical methods:}

\section{a) Water}

Temperature and hydrogen ion concentration $(\mathrm{pH})$ was measured with $\mathrm{pH}$ meter (Model 25, Fisher Scientific). Transparency (cm) was measured, using a Secchi Disc of $20 \mathrm{~cm}$ diameter. Dissolved oxygen was measured by a digital oxygen meter (Model YSI 55). Chlorosity $\left(\mathrm{g} \mathrm{l}^{-1}\right)$, nitrogen compounds $\left(\mathrm{NH}_{4}-\mathrm{N}, \mathrm{NO}_{2}-\mathrm{N}\right.$ and $\left.\mathrm{NO}_{3}-\mathrm{N} \mathrm{mg} \mathrm{l}^{-1}\right)$ phosphate $\left(\mathrm{mg} \mathrm{l}^{-1}\right)$, total alkalinity $\left(\mathrm{mg} \mathrm{l}^{-1}\right)$, and chlorophyll "a" $\left(\mu \mathrm{g} \mathrm{l}^{-1}\right)$ were determined according to Boyd and Tucker (1992).

\section{b) Fish}

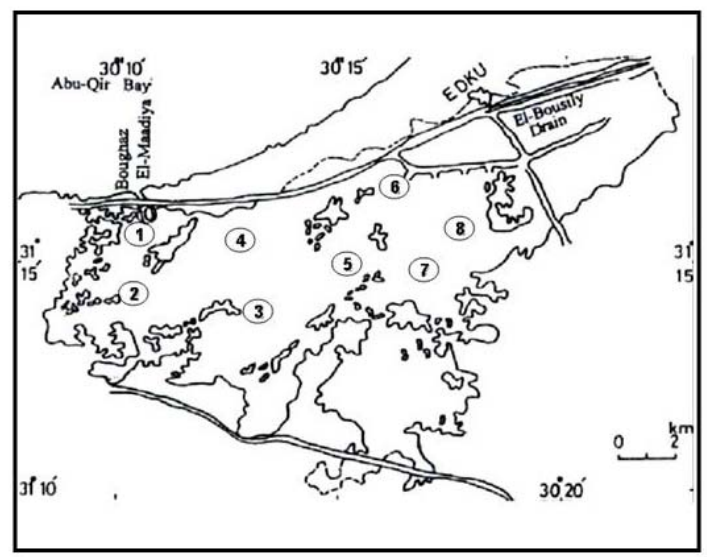

Fig. 1: Study area of Lake Edku

Length-weight relationship and condition factor (CF) were calculated by the following equations: $\mathrm{W}=\mathrm{a} \mathrm{L}^{\mathrm{b}}$ which transformed to the logarithmic formula: $\log \mathrm{W}$ $=\log \mathrm{a}+\mathrm{b} \log \mathrm{L}, \mathrm{K}=\mathrm{W} / \mathrm{L}^{3} \times 100$ where "W", is the total gutted weight in grams, "L" is the total length in cm, "b" is the growth coefficient and "a" is a constant. The hepatosomatic index was also calculated as $\mathrm{HSI}=\left(\mathrm{W}_{\mathrm{L}} / \mathrm{W}_{\mathrm{t}}\right) \times 100$, where $\mathrm{W}_{\mathrm{L}}$ is the liver weight and $\mathrm{W}_{\mathrm{t}}$ the total gutted weight. These growth parameters were estimated according to Schreck and Moyle (1990). Heavy metals (Fe, $\mathrm{Zn}, \mathrm{Cu}, \mathrm{Mn}, \mathrm{Cd}$ and $\mathrm{Pb}$ ) in different muscle tissue of fish as well as moisture, crude protein $(\mathrm{TN} \times$ constant 6.25), total lipid and ash content were determined according to AOAC (2005). Carbohydrate content was calculated by subtracting the sum of protein, fat, water and mineral from the total weight of the food. Atomic Absorption Spectrophotometer (Model Thermo Electron Corporation, S. Series AA Spectrometer, UK) was used for metals detection and the results were expressed as $\mu \mathrm{g} / \mathrm{g}$. dry wt.

\section{Statistical comparisons:}

One-way ANOVA and Duncan multiple range test were used to evaluate the significant difference of the concentration of different items with respect to seasons. Significant differences are stated at $\mathrm{P}<0.05$. Correlation coefficients between the different parameters were computed. Data were statistically analysed according to Bailey (1981). 


\section{RESULTS AND DISCUSSION}

\section{Physical characteristics of water:}

Effects of seasonal variability on physical properties of Lake Edku water are shown in Table 1. Water temperature values in the different stations of the lake were closely followed air temperature with the lowest value of $16.71{ }^{\circ} \mathrm{C}$ during winter and the highest one $\left(28.02{ }^{\circ} \mathrm{C}\right)$ during summer. This range of temperature is suitable for survival and reproduction of warmwater fish. The $\mathrm{pH}$ lies in the alkaline side indicating well-buffered conditions. It showed remarkable difference at different stations of the lake with values ranged between 8.17 during winter and 8.45 during summer season. Variations in $\mathrm{pH}$ values coincided mainly with differences in photosynthetic activities and drainage water. There is a seasonal trend in the $\mathrm{pH}$ values; the highest values were recorded in spring and summer during the outbreak of chlorophyll "a" biomass and aquatic plants. The lowest $\mathrm{pH}$ values appeared in winter where the lake subjected to the increase of sewage wastewater. The desirable $\mathrm{pH}$ range for most fish species is 6-9 (Barker et al., 2009).

Table 1: Seasonal mean and range of variation of physical parameters of Lake Edku water

\begin{tabular}{|c|c|c|c|c|}
\hline $\begin{array}{l}\text { Item } \\
\text { Season }\end{array}$ & Temp $\left({ }^{\circ} \mathrm{C}\right)$ & $\mathrm{pH}$ & SD & Depth $(\mathrm{cm})$ \\
\hline Spring & $\begin{array}{c}24.92 \\
(23.50-25.84)\end{array}$ & $\begin{array}{c}8.34 \\
(8.02-8.75)\end{array}$ & $\begin{array}{c}18.33 \\
(17.21-20.98)\end{array}$ & $\begin{array}{c}110.0 \\
(70-160)\end{array}$ \\
\hline Summer & $\begin{array}{c}28.02 \\
(27.87-29.03)\end{array}$ & $\begin{array}{c}8.45 \\
(8.11-8.79)\end{array}$ & $\begin{array}{c}29.67 \\
(21.33-33.45)\end{array}$ & $\begin{array}{c}105.0 \\
(50-120)\end{array}$ \\
\hline Autumn & $\begin{array}{c}18.82 \\
(18.76-19.17)\end{array}$ & $\begin{array}{c}8.29 \\
(8.07-8.61)\end{array}$ & $\begin{array}{c}32.25 \\
(28.23-36.24)\end{array}$ & $\begin{array}{c}130.0 \\
(80-190)\end{array}$ \\
\hline Winter & $\begin{array}{c}16.71 \\
(15.78-17.33) \\
\end{array}$ & $\begin{array}{c}8.17 \\
(7.92-8.52) \\
\end{array}$ & $\begin{array}{c}19.50 \\
(16.35-29.08) \\
\end{array}$ & $\begin{array}{c}70.0 \\
(50-90) \\
\end{array}$ \\
\hline $\begin{array}{c}\text { Annual } \\
\text { av. }\end{array}$ & 22.12 & 8.31 & 26.19 & 103.75 \\
\hline
\end{tabular}

The Secchi disc readings measure the lake water transparency and assess the water clarity, particularly the density of algae and suspended sediments. The Secchi depth of Lake Edku was high and ranged from $18.33 \mathrm{~cm}$ to $32.25 \mathrm{~cm}$ with annual average value of $26.19 \mathrm{~cm}$. The decrease in the transparency of water is mainly due to inflow of drainage water loaded with suspended particles (silt and clay). The Secchi depth in the lake remained high over the study period due to the high proportion of higher plants in the water. Reduced turbulence leads to the reduction of the resuspension of bottom sediments and resulted in less turbidity in water column. Phytoplankton biomass can also contribute to low Secchi depth in spring and high visibility readings in summer, autumn and winter.

\section{Chemical characteristics of water:}

Chemical characteristics of water are illustrated in Table 2. The annual average of chlorosity for the entire lake reached $1.22 \mathrm{gl}^{-1}$, with a maximum value of $1.42 \mathrm{~g} \mathrm{l}^{-1}$ recorded in summer and a minimum value of $0.89 \mathrm{~g}^{-1}$ observed in autumn. This variation in water chlorosity could attributed to the effect of Abu Qir Bay water inflowing into the lake through the lake-sea connection as well as drainage water come from drains. It is interesting to note that chlorosity values of Lake Edku in this study were near those recorded by Okbah and El-Gohary (2002). This is related to the stable conditions in drains and the amount of drainage water entering the lake. 
Distribution of Dissolved Oxygen (DO) was influenced by external and internal events and showed a considerable wide range of variations in the lake. The minimum recorded concentration was $5.12 \mathrm{mg} \mathrm{l}^{-1}$ in summer. This may be due to several factors as the rise in temperature, increased biological activity, respiration of organisms and the increased rate of decomposition of organic matter (Okbah and El-Gohary, 2002). The highest value $\left(9.42 \mathrm{mg}^{-1}\right)$ was observed in spring and autumn $(8.92 \mathrm{mg} / \mathrm{l})$. This may be as a result of stirring up of water by wind in these seasons as well as low temperature. In general, warmwater species such as tilapia need a dissolved oxygen concentration of $5-15 \mathrm{mg} \mathrm{l}^{-1} \mathrm{DO}$ or greater to maintain good health and feed conversion (Boyd, 1998). So, the lake water appears to be well oxygenated and no sign of oxygen depletion was observed in Lake Edku.

Table 2: Seasonal mean and range of variation of chemical parameters and Chl. "a" of Lake Edku water

\begin{tabular}{|c|c|c|c|c|c|c|c|c|}
\hline $\begin{array}{l}\text { Item } \\
\text { Season }\end{array}$ & Chlorosity & DO & $\mathrm{NH}_{4}-\mathrm{N}$ & $\mathrm{NO}_{2}-\mathrm{N}$ & $\mathrm{NO}_{3}-\mathrm{N}$ & $\mathrm{PO}_{4}-\mathrm{p}$ & T. alk. & Chl. "a" \\
\hline Spring & $\begin{array}{c}1.36 \\
(0.37-2.2)\end{array}$ & $\begin{array}{c}9.4 \\
(7.2-13.3)\end{array}$ & $\begin{array}{c}1.28 \\
(0.72-1.66)\end{array}$ & $\begin{array}{c}0.11 \\
(0.09-0.14)\end{array}$ & $\begin{array}{c}1.36 \\
(0.96-1.74)\end{array}$ & $\begin{array}{c}0.55 \\
(0.51-0.63)\end{array}$ & $\begin{array}{c}217.3 \\
(200.1-231.6)\end{array}$ & $\begin{array}{c}26.2 \\
(22.1-35.2)\end{array}$ \\
\hline Summer & $\begin{array}{c}1.42 \\
(0.47-2.8)\end{array}$ & $\begin{array}{c}5.1 \\
(4.5-6.3)\end{array}$ & $\begin{array}{c}1.09 \\
(0.63-1.34)\end{array}$ & $\begin{array}{c}0.12 \\
(0.08-0.16)\end{array}$ & $\begin{array}{c}0.37 \\
(0.35-0.43)\end{array}$ & $\begin{array}{c}0.22 \\
(0.19-0.27)\end{array}$ & $\begin{array}{c}213.4 \\
(197.2-222.2)\end{array}$ & $\begin{array}{c}16.1 \\
(14.2-17.4)\end{array}$ \\
\hline Autumn & $\begin{array}{c}0.89 \\
(0.54-1.3)\end{array}$ & $\begin{array}{c}8.9 \\
(5.2-11.0)\end{array}$ & $\begin{array}{c}1.13 \\
(0.71-1.33)\end{array}$ & $\begin{array}{c}0.16 \\
(0.10-0.21)\end{array}$ & $\begin{array}{c}0.57 \\
(0.54-0.62)\end{array}$ & $\begin{array}{c}0.36 \\
(0.22-0.41)\end{array}$ & $\begin{array}{c}267.1 \\
(221.0-289.3)\end{array}$ & $\begin{array}{c}19.1 \\
(18.6-21.8)\end{array}$ \\
\hline Winter & $\begin{array}{c}1.21 \\
(0.68-1.8) \\
\end{array}$ & $\begin{array}{c}6.7 \\
(5.1-9.8) \\
\end{array}$ & $\begin{array}{c}2.82 \\
(1.66-4.22)\end{array}$ & $\begin{array}{c}0.21 \\
(0.14-0.26)\end{array}$ & $\begin{array}{c}0.28 \\
(0.22-0.31)\end{array}$ & $\begin{array}{c}0.17 \\
(0.14-0.22)\end{array}$ & $\begin{array}{c}232.2 \\
(211.7-255.6)\end{array}$ & $33.01(25.1-39.3)$ \\
\hline Annual av. & & 7.53 & 1.76 & 0.15 & 0.71 & 0.33 & 232.51 & 23.59 \\
\hline
\end{tabular}

There was a noticeable seasonal variation in total ammonia levels; the lowest ammonia content was recorded in summer and autumn. This is probably due to the utilization of $\mathrm{NH}_{4}-\mathrm{N}$ by phytoplankton and hydrophytes. On the other hand, the increase of total ammonia in winter may be due to the degradation of aquatic plants and phytoplankton and increase of sewage wastewater in relation to agriculture drainage water in this season.

The nitrite content followed the same trend as $\mathrm{NH}_{4}-\mathrm{N}$, where it recorded the highest value in winter $\left(0.15 \mathrm{mg}^{-1}\right)$ and the lowest one in spring and summer $(0.11$ and $0.12 \mathrm{mg} \mathrm{l}^{-1}$ ). The desirable ranges are $0.2-2.0 \mathrm{mg} \mathrm{l}^{-1}$ for total $\mathrm{NH}_{4}-\mathrm{N}$ and $<0.3 \mathrm{mg}$ $1^{-1}$ for $\mathrm{NO}_{2}-\mathrm{N}$ in fish culture (Boyd, 1998).

The higher values of $\mathrm{NO}_{3}-\mathrm{N}$ were recorded in spring and this could be due to the large amounts of drainage water enter the lake in this season. On the other hand, the lower values during summer are mostly due to its assimilation by phytoplankton and aquatic plants. The mean values of $\mathrm{NO}_{3}-\mathrm{N}$ in this study were higher than those recorded by Shakweer (2006). The desirable range of nitrate is ranged from $0.2-10 \mathrm{mg}$ $1^{-1}$ according to Boyd (1998). The present study indicated that total ammonia (sum of $\mathrm{NH}_{4}{ }^{+}-\mathrm{N}+\mathrm{NH}_{3}-\mathrm{N}$ ) was the most dominant constituent of the dissolved inorganic nitrogen compounds in the lake. This may be attributed to the high amounts of organic matter degradation especially at stations near drains, where aquatic plants flourish intensively as well as the effect of sewage wastewater.

The highest values of dissolved phosphate were determined in spring and autumn seasons. The higher concentrations of dissolved phosphate are mostly due to the effect of drainage water enriched with phosphorous compounds. In contrast, this parameter reveals a significant decrease during summer and winter seasons on the basis of the increasing uptake by phytoplankton and decreasing drainage water, respectively. The concentration of all nutrients in this study was higher than those recorded in the same lake by Okbah and El-Gohary (2002) and Shakweer (2006).

The seasonal distribution of total alkalinity (sum of bicarbonate and carbonate) for the entire lake during the period of investigation showed a general decrease in 
summer $\left(213.44 \mathrm{mg}^{-1}\right)$. On the other hand, a significant increase was recorded in the autumn $\left(267.12 \mathrm{mg} \mathrm{l}^{-1}\right)$. The annual average value of total alkalinity was $232.51 \mathrm{mg} \mathrm{l}^{-}$ ${ }^{1}$. The highest values of total alkalinity in Lake Edku during autumn may be attributed to the higher $\mathrm{CO}_{2}$ content produced as a result of increase bicarbonate which comes with drainage water which increases in this season. In contrast, the lower values of total alkalinity during summer may be due to the utilization of $\mathrm{CO}_{2}$ during increase algal and hydrophytes photosynthetic activity. A desirable range of alkalinity is 50$300 \mathrm{mg} \mathrm{l}^{-1}$, but fish survive in waters up to $400 \mathrm{mg} \mathrm{l}^{-1}$ (Barker et al., 2009).

Chlorophyll "a" concentration varied from $16.06 \mu \mathrm{g} \mathrm{l}{ }^{-1}$ during summer, to 33.01 $\mu \mathrm{g} \mathrm{l}^{-1}$ during spring. The lower value during summer is as a result of distribution of immersed and emerged plants, especially the water hyacinths Eichhornia crassipes and the reed Phragmites australis. Shading by emerged plants counteracts the development of algae in the lake.

\section{Heavy metals in fish muscles:}

The study of fish muscle tissues is one of the means for investigating the amount of heavy metals reaching man by food chain. Seasonal variations in the concentrations of the heavy metals ( $\mathrm{Fe}, \mathrm{Zn}, \mathrm{Cu}, \mathrm{Mn}, \mathrm{Cd}$ and $\mathrm{Pb})$ in muscles of the three studied Tilapia spp. are illustrated in Tables 3,4 and 5. The concentrations of tested heavy metals varied considerably with regards to seasons. Muscles of fishes caught during autumn and winter seasons had more heavy metals than those in spring and summer. Mason (2002) mentioned that, feeding results in a higher metabolism and greater uptake of pollutants across the gills may occur in feeding as opposed to starved fish.

Table 3: Seasonal variations of metals concentrations ( $\mu \mathrm{g} / \mathrm{g}$ dry wt.) in muscle tissues of $O$. niloticus.

\begin{tabular}{cccccccc}
\hline $\begin{array}{c}\text { Metal } \\
\text { Season }\end{array}$ & $\mathrm{Fe}$ & $\mathrm{Zn}$ & $\mathrm{Cu}$ & $\mathrm{Mn}$ & $\mathrm{Cd}$ & $\mathrm{Pb}$ & $\begin{array}{c}\text { Total } \\
\text { av. }\end{array}$ \\
\hline Spring & $39.01 \pm 3.21$ & $29.77 \pm 2.06$ & $2.01 \pm 0.36$ & $2.33 \pm 0.28$ & $0.20 \pm 0.02$ & $0.14 \pm 0.02$ & 73.46 \\
Summer & $47.88 \pm 3.36$ & $23.74 \pm 3.12$ & $2.62 \pm 0.11$ & $2.78^{*} \pm 0.34$ & $0.28 \pm 0.06$ & $0.92^{*} \pm 0.13$ & 78.22 \\
Autumn & $70.04^{*} \pm 2.71$ & $30.12 \pm 2.28$ & $2.31 \pm 0.23$ & $2.22 \pm 0.17$ & $0.13 \pm 0.02$ & $0.82^{*} \pm 0.11$ & 105.64 \\
Winter & $89.04^{*} \pm 5.11$ & $47.20^{*} \pm 4.15$ & $3.12^{*} \pm 0.37$ & $2.59^{*} \pm 0.36$ & $0.49^{*} \pm 0.07$ & $0.19 \pm 0.03$ & $142.63^{*}$ \\
\hline Ann. av. & 61.49 & 32.71 & 2.52 & 2.48 & 0.27 & 0.52 & 99.99 \\
\hline
\end{tabular}

Asterisk in the same column shows differences among seasons. ${ }^{*}$ statistically different at $\mathrm{P} \leq 0.05$ level.

Table 4: Seasonal variations of metals concentrations ( $\mu \mathrm{g} / \mathrm{g}$ dry wt.) in muscle tissues of $O$. aureus.

\begin{tabular}{cccccccc}
\hline $\begin{array}{c}\text { Metal } \\
\text { Season }\end{array}$ & $\mathrm{Fe}$ & $\mathrm{Zn}$ & $\mathrm{Cu}$ & $\mathrm{Mn}$ & $\mathrm{Cd}$ & $\mathrm{Pb}$ & Total av. \\
\hline Spring & $44.11 \pm 6.02$ & $33.31 \pm 3.22$ & $2.59^{*} \pm 0.14$ & $1.87 \pm 0.16$ & $0.21 \pm 0.02$ & $0.15 \pm 0.02$ & 82.24 \\
Summer & $86.49^{*} \pm 5.62$ & $29.22 \pm 3.14$ & $1.55 \pm 0.11$ & $4.55^{*} \pm 0.20$ & $1.04^{*} \pm 0.13$ & $1.35 \pm 0.06$ & 124.20 \\
Autumn & $90.14^{*} \pm 7.11$ & $25.16 \pm 2.75$ & $1.80 \pm 0.22$ & $2.46 \pm 0.18$ & $0.18 \pm 0.03$ & $1.46^{*} \pm 0.05$ & 121.20 \\
Winter & $86.11^{*} \pm 8.16$ & $41.17^{*} \pm 4.07$ & $3.13^{*} \pm 0.31$ & $2.02 \pm 0.17$ & $0.29 \pm 0.09$ & $0.21 \pm 0.01$ & $132.93^{*}$ \\
\hline Ann. av. & 76.71 & 32.22 & 2.27 & 2.73 & 0.43 & 0.79 & 115.14 \\
\hline
\end{tabular}

Abbreviation as in Table 3.

Table 5: Seasonal variations of metals concentrations ( $\mu \mathrm{g} / \mathrm{g}$ dry wt.) in muscle tissues of T. zillii.

\begin{tabular}{cccccccc}
\hline $\begin{array}{c}\text { Metal } \\
\text { Season }\end{array}$ & $\mathrm{Fe}$ & $\mathrm{Zn}$ & $\mathrm{Cu}$ & $\mathrm{Mn}$ & $\mathrm{Cd}$ & $\mathrm{Pb}$ & Total av. \\
\hline Spring & $53.64 \pm 4.16$ & $31.91 \pm 5.08$ & $2.93 \pm 0.13$ & $2.47 \pm 0.17$ & $0.39 \pm 0.08$ & $0.11 \pm 0.01$ & 91.45 \\
Summer & $49.89 \pm 6.35$ & $38.53 \pm 3.65$ & $1.67 \pm 0.21$ & $1.31 \pm 0.22$ & $1.47^{*} \pm 0.21$ & $1.71^{*} \pm 0.16$ & 94.58 \\
Autumn & $99.57 \pm 10.26$ & $26.66 \pm 2.45$ & $1.81 \pm 0.19$ & $2.32 \pm 0.15$ & $0.11 \pm 0.02$ & $0.91 \pm 0.12$ & 131.38 \\
Winter & $132.99^{*} \pm 9.87$ & $89.11^{*} \pm 11.03$ & $6.01^{*} \pm 0.99$ & $3.19^{*} \pm 0.44$ & $1.00 \pm 0.13$ & $0.49 \pm 0.12$ & $232.79^{*}$ \\
\hline Ann. av. & 84.02 & 46.55 & 3.11 & 2.32 & 0.74 & 0.81 & 137.55 \\
\hline
\end{tabular}

Abbreviation as in Table 3. 
Metals accumulated in the three species in the order of T. zillii $>$ O. aureus $>O$. niloticus. T. zillii seemed to accumulate most of the studied trace elements in their muscles at higher rates than $O$. aureus and $O$. niloticus, which reflects its high affinity to heavy metals uptake more than the other species. In addition, these observations are mainly due to the different feeding habits and physiology in relation to the surrounding habitats. This can also be explained by the fact that T. zillii and O. aureus feed mostly on tissues of higher hydrophytes (Abdel-Baky, 1989). For freshwater fish, the uptake of metals through their food may be quite substantial (Dallinger et al., 1987), and metals taken up by plants can be an important route to make metals in sediments bioavailable herbivore species like tilapia. This complies with Nwajei et al. (2012) who observed that Tilapia zillii accumulated the highest heavy metal levels than others from the Niger River.

The order of metals distribution in muscle tissues of studied Tilapia spp. were $\mathrm{Fe}>\mathrm{Zn}>\mathrm{Cu}>\mathrm{Mn}>\mathrm{Pb}>\mathrm{Cd}$. The low concentration of $\mathrm{Cd}$ might be due to its low tendency to bioaccumulation or good ability to it's excreting from the body. These findings are similar to those obtained by Ibrahim et al. (2008). It is obvious that, the levels of all heavy metals detected were under the permissible values recommended by SCF (1993), IPCS (1998) and WHO (2011), where the daily intake for an adult is 50, 30, 5.0, 10.0, 0.05 and $0.214 \mathrm{mg}$ /day wet weight for $\mathrm{Fe}, \mathrm{Zn}, \mathrm{Cu}, \mathrm{Mn}, \mathrm{Cd}$ and $\mathrm{Pb}$, respectively. So, a normal daily diet including studied fish species poses no health risk to consumer.

\section{Fish condition:}

The growth coefficient (b), condition factor (CF) and hepato-somatic index are essential biological parameters used to asses the condition of fish such as degree of fatness and the suitability of the environment with regard to the feeding condition (Schreck and Moyle, 1990). The growth coefficient (b) was 3 or close to 3 in majority of seasons, accompanied by $\mathrm{K}$ values more than 1.0. These observations clearly indicate better growth and health (well being) of studied tilapia species in Lake Edku. The results showed that, $T$. zillii had the highest growth coefficient $\left(\mathrm{b}=3.02, \mathrm{R}^{2}=0.98\right)$ followed by $O$. niloticus $\left(b=2.90, \mathrm{R}^{2}=0.97\right)$, while $O$. aureus had the lowest value $\left(b=2.76, R^{2}=0.98\right)$ (Table 6). These results are in agreement with Abdel-Baky and ElSerafy (1990) who recorded higher exponent (b) for T. zillii than O. niloticus in Lake Manzalla. Also, Kumolu and Ndimele (2011) recorded similar (b) values for T. zillii, O. niloticus and O. aureus, in Ologe Lagoon, Nigeria.

Table 6: Equations of length-weight relationship of different studied cichlid species in Lake Edku

\begin{tabular}{|c|c|c|c|c|c|}
\hline Fish species & Spring & Summer & Autumn & Winter & All \\
\hline & \multicolumn{4}{|c|}{ Log "a" } & \\
\hline O. niloticus & -1.4800 & -1.7253 & -0.9817 & -1.8999 & -1.5217 \\
\hline O. aureus & -1.4117 & -1.2031 & -1.3487 & -1.6104 & -1.3935 \\
\hline \multirow[t]{2}{*}{ T. zillii } & -1.6183 & -1.5941 & -1.1192 & -1.4987 & -1.4576 \\
\hline & \multicolumn{4}{|c|}{ Regression (growth) coefficient (b) } & \\
\hline O. niloticus & 3.0024 & 2.6157 & 2.9765 & 2.9913 & 2.9001 \\
\hline O. aureus & 2.8523 & 2.6024 & 2.6947 & 2.9012 & 2.7627 \\
\hline \multirow[t]{2}{*}{ T. zillii } & 3.1217 & 2.8577 & 2.9101 & 3.2258 & 3.0288 \\
\hline & \multicolumn{4}{|c|}{ Correlation coefficient $\left(\mathrm{R}^{2}\right)$} & \\
\hline O. niloticus & 0.9589 & 0.9628 & 0.9814 & 0.9799 & 0.9708 \\
\hline O. aureus & 0.9718 & 0.9874 & 0.9825 & 0.9935 & 0.9838 \\
\hline T. zillii & 0.9892 & 0.9897 & 0.9641 & 0.9957 & 0.9847 \\
\hline
\end{tabular}


Concerning fish species, O. niloticus showed the highest condition factor, while $O$. aureus the lowest one. The annual condition factor (CF) was 1.72, 1.53 and 1.68 for $O$. niloticus, $O$. aureus and $T$. zillii, respectively and varied significantly among different seasons $(\mathrm{P}<0.05)$ (Table 7). These results in accordance with that of Soliman et al. (1998) in Lake Manzala and Koussa (2000) in Lake Mariut who mentioned that $O$. niloticus had the highest $\mathrm{CF}$ value among different tilapia species and attributed the increase in fish growth to the high productivity of water. The best condition factor for all studied fishes was observed in spring and winter (i.e. before and after spawning). The lowest fish condition factor was recorded during the spawning season in summer (Table 7). The low summer values may result from lower food availability (lower chlorophyll a) and the mobilization of somatic energy reserves needed for reproductive development. In autumn, the fish regains its weight lost during the long period of spawning, incubation of eggs and larval metamorphoses. Weatherly and Gill (1987) observed a remarkable reduction in condition factor during breeding periods and dry seasons because of fish starvation.

The annual values of hepatosomatic index (HSI) were 1.42, 1.87 and 1.59 for $O$. aureus, O. niloticus and T. zillii, respectively. O. aureus showed the highest value of HSI, while O. niloticus the lowest one. This may be related to that T. zillii and $O$. aureus eat the higher plant tissues rich in glycogen. Abdel-Baky et al. (1989) and Abdel-Baky (1997) mentioned that these plant tissues composed the highest percentage of the food items in gut of T. zillii and O. aureus, while O. niloticus are specialized microphages (i.e. feed mainly on phytoplankton) in Lake Manzalah.

Table 7: Seasonal and annual variations of condition factor (CF) and hepatosomatic index (HSI) of $O$. niloticus, O. aureus and T. zillii inhabiting Lake Edku

\begin{tabular}{cccccc}
\hline Fish species & Spring & Summer & Autumn & Winter & $\begin{array}{c}\text { \#Annual } \\
\text { av. }\end{array}$ \\
\hline O. niloticus & 1.81 & 1.53 & 1.62 & $1.92^{* *}$ & $1.72^{* *}$ \\
O. aureus & 1.61 & 1.30 & 1.40 & $1.79^{*}$ & 1.53 \\
T. zillii & 1.78 & 1.50 & 1.58 & $1.84^{*}$ & 1.68 \\
Average & 1.73 & 1.44 & 1.53 & $1.85^{*}$ & 1.64 \\
& \multicolumn{5}{c}{ HSI } \\
O. niloticus & $1.48^{* *}$ & 1.26 & 1.38 & 1.56 & 1.42 \\
O. aureus & 1.93 & 1.68 & 1.87 & $2.01^{* *}$ & $1.87^{* *}$ \\
T. zillii & $2.12^{* *}$ & 1.12 & 1.57 & 1.70 & 1.59 \\
\hline Average & $1.89^{*}$ & 1.35 & 1.61 & $1.76^{*}$ & 1.63 \\
\hline Asting
\end{tabular}

Asterisk in rows: comparison between the same species in different seasons. Asterisk in annual average column: comparison between the different species (for CF \& HSI). * significant at $\mathrm{P} \leq 0.05$; ** significant at $\mathrm{P} \leq 0.001$

HSI values varied significantly between seasons; in spring being significantly higher $(\mathrm{P}<0.05)$ than all other seasons for O. niloticus and T. zillii, whereas in winter for O. aureus (Table 7). Also, HSI showed highest values in spring and winter for pooled fish. The high values are confirmed by the high condition factor and the improved growth of fish as previously reported by Weatherly and Gill (1987).

The higher values of HSI can be attributed to the enlargement of the liver due to the swollen hepatocytes with glycogen. A decrease of liver size in summer and autumn may be as a consequence of a loss of hepatic glycogen and/or lipid which is a common morphologic response of fish liver to stress (spawning and reproduction) that enhance utilization of glycogen as an immediate source to meet the energy demand during spawning seasons (Schreck, 1981). 


\section{Proximate composition analysis:}

The proximate analysis of studied cichlid spp. flesh caught during different seasons is shown in Tables 8, 9 and 10. Its average were $80.57 \%$ moisture, $16.63 \%$ protein, $1.19 \%$ lipid, $1.32 \%$ ash and $0.30 \%$ carbohydrate content (on wet wt. basis) in O. niloticus (Table 8). The corresponding values in O. aureus were $81.66 \%$ moisture, $15.63 \%$ protein, $1.12 \%$ lipid, $1.31 \%$ ash and $0.28 \%$ carbohydrate content (Table 9). On the other hand, the chemical composition of Tilapia zillii was $80.45 \%$ moisture, $16.51 \%$ protein, $1.30 \%$ lipid, $1.24 \%$ ash and $0.37 \%$ carbohydrate content (Table 10 ).

Table 8: Seasonal changes in proximate composition of O. niloticus

\begin{tabular}{lccccc}
\hline & $\begin{array}{c}\text { Moisture } \\
(\%)\end{array}$ & Protein (\%) & Fat (\%) & Ash (\%) & $\begin{array}{c}\text { Carbohydrate } \\
(\%)\end{array}$ \\
\hline Spring & $80.14 \pm 0.25$ & $17.03^{*} \pm 0.28$ & $1.23 \pm 0.18$ & $1.21 \pm 0.08$ & $0.40^{*} \pm 0.08$ \\
Summer & $81.64^{*} \pm 0.11$ & $15.45 \pm 0.22$ & $1.04 \pm 0.12$ & $1.57^{*} \pm 0.07$ & $0.30 \pm 0.02$ \\
Autumn & $80.26 \pm 0.16$ & $16.94 \pm 0.15$ & $1.14 \pm 0.11$ & $1.33 \pm 0.11$ & $0.33 \pm 0.06$ \\
Winter & $80.22 \pm 0.22$ & $17.09^{*} \pm 0.23$ & $1.34^{*} \pm 0.09$ & $1.17 \pm 0.06$ & $0.18 \pm 0.03$ \\
\hline Average & 80.57 & 16.63 & 1.19 & 1.32 & 0.30 \\
\multicolumn{1}{c}{ SD } & 0.72 & 0.79 & 0.13 & 0.18 & 0.09 \\
\hline
\end{tabular}

Values with asterisk within the same column are significantly different at $\mathrm{P} \leq 0.05$.

Table 9: Seasonal changes in proximate composition of O. aureus

\begin{tabular}{lccccc}
\hline & $\begin{array}{c}\text { Moisture } \\
(\%)\end{array}$ & Protein $(\%)$ & Fat $(\%)$ & Ash $(\%)$ & $\begin{array}{c}\text { Carbohydrate } \\
(\%)\end{array}$ \\
\hline Spring & $81.77 \pm 0.21$ & $15.55 \pm 0.22$ & $1.13 \pm 0.08$ & $1.29 \pm 0.14$ & $0.26 \pm 0.03$ \\
Summer & $81.78 \pm 0.26$ & $15.48 \pm 0.19$ & $1.01 \pm 0.10$ & $1.41^{*} \pm 0.11$ & $0.32^{*} \pm 0.02$ \\
Autumn & $82.45^{*} \pm 0.19$ & $14.75 \pm 0.21$ & $1.11 \pm 0.09$ & $1.40^{*} \pm 0.16$ & $0.29 \pm 0.03$ \\
Winter & $80.65 \pm 0.31$ & $16.75^{*} \pm 0.16$ & $1.23^{*} \pm 0.11$ & $1.12 \pm 0.10$ & $0.25 \pm 0.04$ \\
\hline Average & 81.66 & 15.63 & 1.12 & 1.31 & 0.28 \\
\multicolumn{1}{c}{ SD } & 0.75 & 0.83 & 0.09 & 0.13 & 0.03 \\
\hline
\end{tabular}

Values with asterisk within the same column are significantly different at $\mathrm{P} \leq 0.05$.

Table 10 Seasonal changes in proximate composition analysis of T. zillii

\begin{tabular}{lccccc}
\hline & $\begin{array}{c}\text { Moisture } \\
(\%)\end{array}$ & Protein $(\%)$ & Fat $(\%)$ & Ash $(\%)$ & $\begin{array}{c}\text { Carbohydrate } \\
(\%)\end{array}$ \\
\hline Spring & $79.87 \pm 0.16$ & $17.31^{*} \pm 0.19$ & $1.36^{*} \pm 0.12$ & $1.07 \pm 0.04$ & $0.39 \pm 0.01$ \\
Summer & $81.79^{*} \pm 0.22$ & $14.64 \pm 0.17$ & $1.18 \pm 0.10$ & $1.48^{*} \pm 0.09$ & $0.31 \pm 0.04$ \\
Autumn & $80.19 \pm 0.17$ & $16.81 \pm 0.22$ & $1.19 \pm 0.09$ & $1.40^{*} \pm 0.11$ & $0.42^{*} \pm 0.06$ \\
Winter & $79.93 \pm 0.21$ & $17.26^{*} \pm 0.11$ & $1.46^{*} \pm 0.14$ & $0.99 \pm 0.03$ & $0.36 \pm 0.04$ \\
\hline Average & 80.45 & 16.51 & 1.30 & 1.24 & 0.37 \\
SD & 0.91 & 1.26 & 0.14 & 0.24 & 0.05 \\
\hline
\end{tabular}

Values with asterisk within the same column are significantly different at $\mathrm{P} \leq 0.05$.

The variation in chemical composition of Tilapia species was affected by seasonal variation. In different environmental conditions, the values of body composition of the same fish may differ in relation to difference in water quality, feeding conditions, sex, state of maturity (Javaid et al., 1992) and capture period of the fish (Oliveira et al., 2003). An increase in protein, fat and decrease in water content showed in spring and winter and vise versa in summer and autumn. This coincides with Love (1980), who mentioned that a decrease in water content and increase in fat content of fish is attributed to good condition, while the water content of non-fatty muscles rises during non-feeding or fasting conditions, due to utilization of protein for metabolic activities.

In this study, fish condition (CF and HSI) varied among different seasons (Table 7) and showed a direct relationship with primary productivity (chlorophyll "a") but with no significant difference $(\mathrm{P}>0.05)$. This may be indicated that other food 
materials (e.g. aquatic plants) affect fish growth beside chlorophyll "a". Also, spawning and reproduction play an important role in decreasing fish growth parameters. These results of seasonal changes in water quality and growth factors comply with Offem et al. (2011) who concluded that water quality, plankton and fish production of the aquatic system influenced by seasons. Also, Das (1977) mentioned that in areas, where seasonal fluctuations in ecological condition are more pronounced, changes in condition factor are often related with feeding and seasonal cycles. Also, it is clear that there is a direct relationship between chemical composition and condition of fish. The results obtained by Naeem and Ishtiaq (2011) confirm the fact that proximate composition of fishes varies with species, body size and condition factor.

In conclusion, this study proved that environmental factors as climate (seasonal variations and temperature) and drainage wastewater affect the physical and chemical characteristics of water as well as fish condition and quality.

\section{REFERENCES}

Abdel-Baky, T. E.; El-Serafy, S. S. and El-Ghobashy, A. (1989). Studies on the food and feeding habits of four species of cichlid fishes in the western region of Manzala Lake, Egypt. Mans. Sci. Bull., 17 (1): 411-428.

Abdel-Baky, T. E. and El-Serafy, S. S. (1990): Length-weight relationship and relative condition factor of three species of cichlid fishes inhabiting Lake Manzala, Egypt. Bull. Inst. Oceanogr. \& Fish., 16 (1): 147-169.

Abdel-Baky, T. E. (1997). Food habits of four cichlid species according to their length variations in Lake Manzala, Egypt. J. Egypt. Ger. Soc. Zool., 23 (B): 45-57.

AOAC. (2005). Official Methods of Analysis of AOAC International. $18^{\text {th }}$ ed., AOAC International, Gaithersburg, MD, USA.

Badr, N. B. and Hussein, M. M. (2010). An Input/ Output Flux Model of Total Phosphorous in Lake Edku, a Northern Eutrophic Nile Delta Lake. Global J. Environ. Res., 4 (2): 64-75.

Bailey, N. T. (1981). Statistical Methods in Biology. $2^{\text {nd }}$ ed. (Biological Science Texts).

Barker, D.; Allan, G. L.; Rowland, S. J.; Kennedy, J. D. and Pickles, J. M. (2009). A Guide to Acceptable Procedures and Practices for Aquaculture and Fisheries Research. $3^{\text {rd }}$ Edition. Primary Industries (Fisheries) ACEC. Nelson Bay, Australia.

Boyd, C. and Tucker, C. (1992). Water quality and pond soil analysis for aquaculture. Alabama agric. experimental station. Auburn. Uni. 183 pp.

Boyd, C. E. (1998). Water Quality for Pond Aquaculture. Research and Development Series No. 43. International Center for Aquaculture and Aquatic Environments, Alabama Agricultural Experiment Station, Auburn University, Alabama.

Chobot, M. and Banaś, K. (2008). Seasonal changes of environmental conditions in the phytolittoral zone of Lake Ostrowite in the Bory Tucholskie National park. Limnological Review, 8(3): 87-96.

Dallinger, R.; Prosi, F.; Segner, H. and Back, H. (1987). Contaminated food and uptake of heavy metals by fish: a review and a proposal for further research. Oecologia (Berlin), 73: 91-98.

Das, H. P. (1977). "Length - weight relationship and relative condition of grey mullet, Mugil cephalus L.," Maha Sagar., 10 :145-149. 
El-Wakil, H. F.; Seehy, M. A.; El-Dahhar, A. A.; Ibrahim, M. M.; Hemeida, A. A. and Abass, N. Y. (2008). The Effect of Environmental Condition on Genetic Background in Nile Tilapia (Oreochromis niloticus). J. Arab. Aquac. Soc., 5(1): 101-118.

GAFRD (General Authority for Fishery Resources Development). (2012). Year-Book of fishery statistics in Egypt (2001-2010), Cairo.

Gharib, S. M. and Soliman, A. M. (1998). Some water characteristics and phytozooplankton relationship in Lake Edku (Egypt) and adjacent sea. Bull. Fac. Sci. Alex. Univ., $38(1,2): 25-44$.

Hamill, K.D. and Verburg, P. (2010). Lake water quality in New Zealand 2010: Review of monitoring and reporting. Ministry for the Environment. Available online: http://www.

Ibrahim, S. M.; Shalloof, K. A. and Salama, H. M. (2008). Effect of Environmental Conditions of Abu-Zabal Lake on Some Biological, Histological and Quality Aspects of Fish. Global Veterinaria, 2 (5): 257-270.

IPCS EHC 200 Copper. (1998). Environmental Health Criteria 200. World Health Organization, Geneva.

Javaid, M. Y.; Salam, A.; Khan, M. N. and Naeem, M. (1992). Weight-length and condition factor relationship of a fresh water wild Mahaseer (Tor putitora) from Islamabad (Pakistan). Proc. Pakistan Cong. Zool., 12: 335-340.

Koussa, A. A. (2000). Effect of industrial and organic pollution on potential productivity and fish stock of Lake Mariut, Northern Egypt with a predictive study of that effect on the Lake. Ph. D. Thesis, Fac. Sci., Ain Shams Univ.

Kumolu, C. A. and Ndimele, P. E. (2011). Length-weight relationships of nine fish species from Ologe Lagoon, Lagos, Nigeria. African J. Biotech., 10(2): 241-243.

Love R. M. (1980). The chemical biology of fishes, Vol. II, Academic Press, London.

Mason, C. F. (2002). Biology of freshwater pollution. $4^{\text {th }}$ ed. Essex Univ. England. $387 \mathrm{pp}$.

Naeem, M.; Salam, A.; Baby, R.; Ishtiaq, A. and Rasool, S. (2011). Study of Body Composition of Female Population of Farmed Oreochromis mossambicus in relation to Body Size and Condition Factor from Pakistan. Int. Conf. Biosc., Bioch. and Bioinf. IPCBEE, 5: 360-363.

Nwajei G.; Obi-Iyeke, G. and Okwagi, P. (2012). Distribution of selected trace metal in fish parts from the River Niger. Res. J. Recent Sci., 1(1): 81-84.

Najafpour, S.; Alkarkhi, A. F.; Kadir, M. O. and Najafpour, G. D. (2008). Evaluation of spatial and temporal variation in river water quality. Int. J. Environ. Res., 2 (4), 349-358.

Offem B. O.; Ayotunde, E. O.; Ikpi, G. U.; Ochang, S. N. and Ada, F. B. (2011). Effect of seasons on water quality and biodiversity of Ikwori Lake, south-eastern Nigeria. J. Environ. Prot., 2: 305-323.

Okbah, M. and El-Gohary, S. (2002). Physical and Chemical Characteristics of Lake Edku Water, Egypt. Mediterr. Mar. Sci., (3/2): 27-39.

Oliveira, E. R.; Agostinho, A. A.; Matsushita, M. (2003). Effect of Biological Variables and Capture Period on the Proximate Composition and Fatty Acid Composition of the Dorsal Muscle Tissue of Hypophthalmus edentatus (Spix, 1829). Braz. Arch. Biol. Technol., 46: 105-114.

Saliu, J. K.; Joy, O. and Catherine, O. (2007). Condition factor, fat and protein content of five fish species in Lekki Lagoon, Nigeria. Life Science J., 4: 54-57.

SCF (1993). Reports of the Scientific Committee for Food. Thirty-first series. Nutrient and energy intakes for the European Community. 
Schreck, C. B. (1981). Stress and compensation in teleoste fishes. Response to social and physicol factors. In: "Stress and Fish". (Pickering, A.D. ed.). Academic Press, New York, pp. 295-321.

Schreck, C. B. and Moyle, P. B. (1990). "Methods of Fish Biology". American Fisheries Society; Bethesda, Maryland, USA

Shakweer, L. (2006). Impacts of drainage water discharge on the water chemistry of Lake Edku. Egyptian J. of Aquat. Res., 32 (1): 264-282.

Siam, E. and Ghobrial, M. (2000). Pollution influence on bacterial abundance and chlorophyll-a concentration: case study at Idku Lagoon, Egypt. Sci. Mar., 64 (1): $1-8$.

Soliman, I. A.; Shawky, K. A. and El-Agamy, A. E. (1998). Some biological aspects of four cichlid species in Lake Manzala. Bull. Inst. Oceanogr. \& Fish., 24: $313-$ 323.

Soliman, A. M. (1983). Quantitative and qualitative studies of the plankton of Lake Edku in relation to the local environmental conditions and to fish food M.Sc. Thesis, Faculty. Sci., Alex. Univ., 220 pp.

Touhata, K.; Toyohara, H.; Tanaka, M.; Tokuda, Y.; Sakaguchi, M. and Tanaka, H. (1998). Seasonal change in muscle firmness and proximate composition of red seabream. Fish. Sci., 64: 513-516.

Wassef E. A. and Shehata, M. B. (1991). Biochemical composition of gilthead bream Sparus aurata L. from Lake Bardawil (Egypt). J.K.A.U. Mar. Sci., 2: 111-122.

Weatherly, A. H. and Gill, H. S. (1987). Relative growth of tissues at different somatic growth rates in rainbow trout (Salmo gairdeneri). J. Fish. Biol., 22: 4360 .

World Health Organization WHO. (2011). Iron, Zinc, Copper, Manganese, Cadmium and Lead in drinking-water. Guidelines for drinking-water quality, Geneva, World Health Organization. $4^{\text {th }}$ ed.

\section{ARABIC SUMMARY}

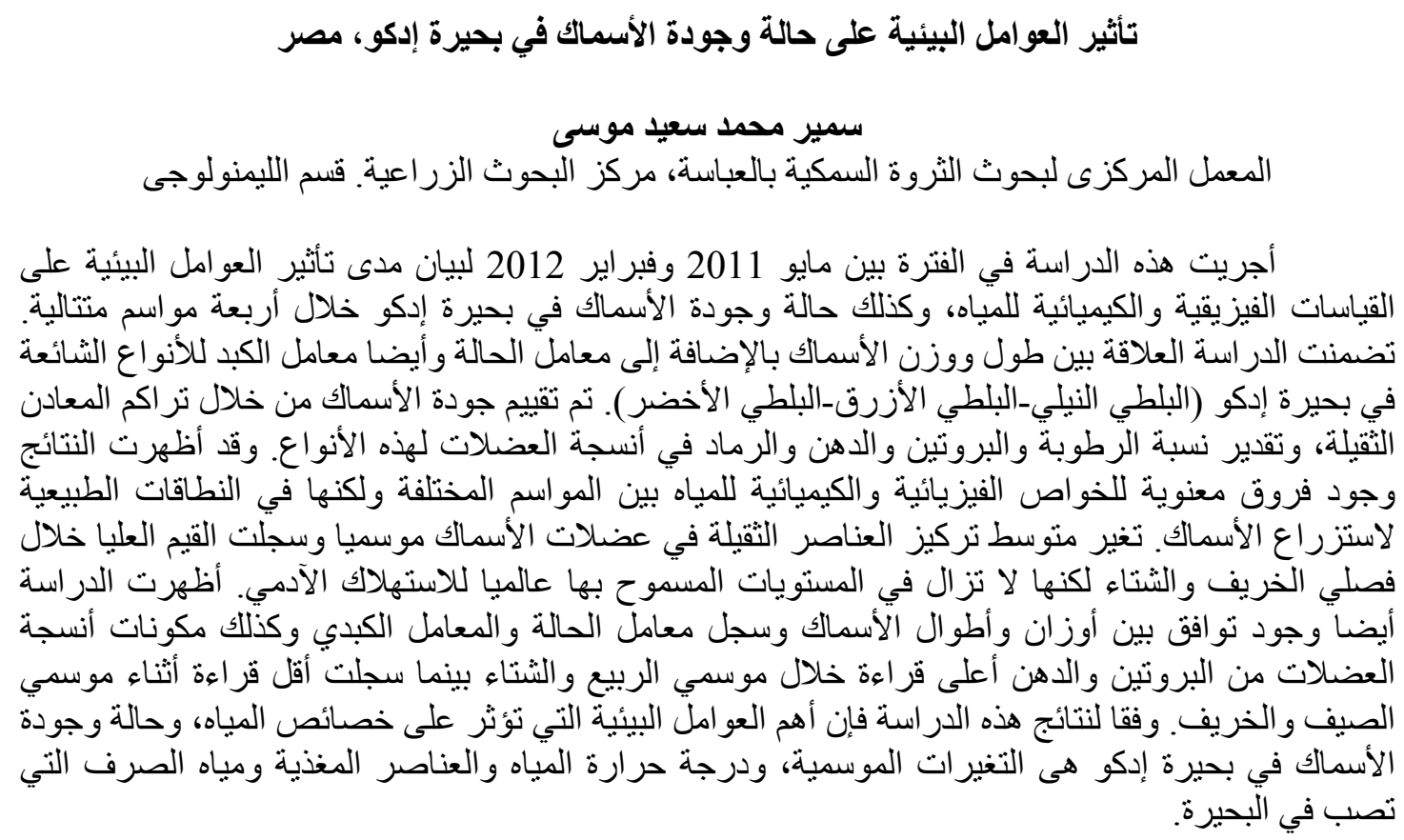

